\title{
Exploring Real and Imaginary Place Names of Medieval French Romance: A Network Visualization Approach
}

\begin{abstract}
This article explores a method of looking at both real and imaginary place name occurrences that co-occur in a corpus of medieval French courtly literature. It uses a dataset of normalized place name spellings and the names of works in which they are found, extracted automatically from a digitized canonical place name index, Louis-Fernand Flutre's Table des noms propres avec toutes leurs variants figurant dans les romans du Moyen Âge écrits en français ou en provençal et actuellement publiés ou analysés (1962). Instead of visualizing this geographic information on a map, we visualize the data as a force-directed graph of places and works. The method offers a means of accounting for the recurrence of both real and imaginary names, the latter being unmappable on normative map interfaces. Important findings of this article's analysis are threefold: many places that are difficult to geo-locate are also mentioned only once in Flutre's corpus of 221 works; subgenres of romance have a kind of spatial imprint, that is, many of the same places are shared between them; and at the center of the network of shared places in medieval French romances sit a number of highly weighted, that is, quite recurrent Mediterranean and central European places.
\end{abstract}

Keywords: Place Names; Medieval French Literature; Spatial Humanities; Networks; Louis-Fernand Flutre.

\section{Introduction}

The impulse to understand the relationship between a text and the place names contained within it is quite strong among editors and literary historians trying to historicize - one might say to geo-historicize- a text's relationship with the world. Even works that are set in largely imaginative landscapes, can be, in fact, quite geo-referential, by which I mean that one finds numerous mentions of places inside of them that resemble known, real places in the world. In literary historical research, a significant effort is expended in the disambiguation of place names

David Joseph Wrisley, New York University Abu Dhabi

D Open Access. (C) 2019 David Joseph Wrisley, published by De Gruyter. (c) BY-NC-ND This work is licensed under the Creative Commons Attribution-NonCommercial-NoDerivatives 4.0 License. https://doi.org/10.1515/9783110585421-017 
in order to locate individual texts in space and in time. Likewise, spatial humanities research on corpora in premodern languages other than English requires a substantial investment of time, since resources for automated geo-referencing are not robust in historical domains. Whereas the scale of reading usually encountered in geo-historical literary research is that of a single text or a small group of works, the researcher working with digital tools typically aims to analyze a larger sample of works, what we call a corpus. This article focuses on the place names found within the larger corpus of medieval French romance. It describes an experiment in data extraction and network visualization (instead of mapping) of co-occurring place names in romances. This method is arguably better adapted to the nature of place names in romance that do not usually occur in the context of topographic description of real, physical settings, but rather as more abstract topoi -a number of interrelated topics within texts referring more generally to places of the world. In the absence of a historical gazetteer for medieval French, that is, a handlist of names mentioned in vernacular writing, this article hopes to provide an initial exploration of the common places found in one corpus, that of medieval French romance. If we wager that the study of intertextuality should include the shared notions of place, then one starting point we can adopt for such analysis is a well-known, yet heretofore unexplored, resource for literary history at scale: the printed place name index.

\section{Collections of medieval geographic information}

It has been argued that collecting and visualizing the geographic information of texts is a rich scholarly endeavor in as much as it allows us to explore visual patterns of similar, or nearby, places occurring within a corpus, encouraging us to use real world places as spatial contexts for pursuing literary historical research (Wrisley 2017: S145-S146). Studying the places of a specific genre allows us to reconstruct the world named within its texts, and to reflect on the semantics of place, much as we might by study changing semantics over time or across genre in a corpus-based analysis of literary texts (Biber 2011: 15-23). If geo-visualization is one of the desired goals of such research, that is to say, if we want to plot places on a contemporary map interface, there are a number of non-trivial technical hurdles to surmount, particularly related to the accuracy of the extraction, disambiguation and geo-resolution of those place names using digital resources, for names that may have changed over time or that exhibit significant orthographic variance (Borin/Dannélls/Olsson 2014: 400-404). Spatial humanities approaches are relatively new, they have largely focused on English-language contexts, and 
they have had limited purchase within medieval studies. In my opinion there are a number of reasons for this fact: limited spatial infrastructure for the multilingual, post-classical period; issues related to information extraction in the context of language change and diachronic toponymy; as well as limited "microspatial knowledge" of the period (Harrison 1996: 2-7). In addition to these reasons, medieval literary texts are replete with many places that are either fictional or that are not easily associated with real-world geographic locations. The analysis in this article does not try to "put the past on the map" (Henige 2007: 237-253), but instead it examines medieval French place names in romance by looking at their frequency in specific works.

Madeleine Jeay argues that collecting place names is also a medieval preoccupation observable in the propensity of medieval authors to make lists and catalogs including geographical ones (Jeay 2006: 44). It is true that an encyclopedic tendency exists in selected medieval French works -an example of the topos of accumulatio- but also in works with a flair for digression, such as the Renart le Contrefait where Spanish geographies feature importantly. Documenting medieval list-making is not the approach taken in this article. Our approach resembles more that of Léonard Dauphant who uses places mentioned in a large numbers of texts to provide insight into popular notions of nation. In our case, however, we do not limit ourselves to places located within historical or contemporary borders of France (Dauphant 2018: 7-13). We adopt a corpus-based approach to place names, akin to what researchers in natural language processing call "detección del foco geográfico" [detection of the geographical focus] of texts and what spatial humanists call "distant reading of the geographies in text corpora" (Peregrino/Tomás/Llopis 2013: 69-70; Donaldson/Murrieta-Flores/Gregory 2016: 10). Such a body of texts - a corpus- is not only a large number of texts; it is a post facto construction, a research apparatus designed to study "traits that can be more easily abstracted, and hence programmed” (Moretti 2017: 2).

There are two general aspects of geographic names taken from literary sources that underlie this article. First, scholarly print reference works about literature such as indexes and dictionaries contain a significant amount of data; they are collections that are accessible to computer-assisted analysis (Padilla 2017: n.p.). Second, I suggest that if we think about place names, without attempting to map them, we can create a weighted network of common places in a genre-specific corpus. Unlike "knowledge graphs" that model complex semantic relationships (Haslhofer/Isaac/Simon 2018: 1-11), our networks are simpler, since they are based on plain co-occurrence across literary texts. They are not the only way that one can model places found in common texts, but it is a way that can be done quite easily. Networks of co-occurrence provide us with exploratory visual models that provide convenient "entry points" (Barbaresi 2018: 27) into texts with 
repetitive geographical markers. Finally, I argue that a text's mention of a place is as much a topic as it is a reference to the real world. This fact perhaps allows us to play on the multivalence of the notion in rhetoric of the topos as a "place in common", a place shared across the corpus, but also a place as a structuring locus for computational reading.

To my knowledge, scholars in medieval French and Occitan have seven major reference works at their disposal, documenting the proper names found in vernacular literary sources. In chronological order of their publication they are Ernest Langlois's Table des noms propres de toute nature compris dans les chansons de geste imprimées (1904), Louis-Fernand Flutre's Table des noms propres avec toutes leurs variantes figurant dans les romans du Moyen Âge écrits en français ou en provençal et actuellement publiés ou analysés (1962), Wilhelmina M. Wiacek's Lexique des noms géographiques et ethniques dans les poésies des troubadours des XIIe et XIIIe siècles (1968), G.D. West's An Index of Proper Names in French Arthurian Verse Romances: 1150-1300 (1969), Frank M. Chambers's Proper Names in the Lyrics of the Troubadours (1971), G.D. West's An Index of Proper Names in French Arthurian Prose Romances (1978) and André Moisan's Répertoire des noms propres de personnes et de lieux cités dans les chansons de geste françaises et les œuvres étrangères dérivées (1986). Obvious from the titles of these works is how genre defines the scope of these indexes. Indeed, they are not all of equal scale or coverage, and they are certainly not representative of the entirety of medieval French literature, owing to the fact that each of the authors used the critical editions available at different moments of the twentieth century. They are, as Flutre's title underscores, a state of knowledge of what had been "actuellement publiés ou analysés" [currently published and analyzed]. The work published in these six reference sources is, I argue, a kind of spatial humanities avant la lettre. In this article I use Flutre's Table des noms propres avec toutes leurs variantes figurant dans les romans du Moyen Âge écrits en français ou en provençal et actuellement publiés ou analysés (henceforth Table), not because it is newer or more inclusive of the textual tradition, but for a more pragmatic reason: it distinguishes names of persons and names of places, listing them in separate sections of the Table "pour des raisons de clarté" [for the sake of clarity] (Flutre 1962: v).

\section{The Context and Content of Flutre's Table}

Louis-Fernand Flutre (1892-1978) was a professor of French literature in Lyons. As he describes in the introduction to the Table, his project documenting place names in medieval French and Occitan romance began in the 1940s in an attempt 
to extend what Langlois did some four decades previous for the chansons de geste. Although Flutre's title for the Table does not contain the term "litterature courtoise" [courtly literature], this is how he described the corpus with which he worked after the fact (Flutre 1971: 401):

[M]a Table des noms des romans courtois, qui se référait aussi bien aux romans imités de l'antiquité (cycle d'Alexandre, romans de Thèbes, d'Enéas et de Troie) qu'aux romans bretons (légende de Tristan et Iseut, romans arthuriens, cycle du Graal); à des récits en prose tout comme à des oeuvres en vers; à des romans d'aventure et aussi à des nouvelles, à des lais, à des débats, à la chantefable d'Aucassin et Nicolette, etc., en tout à 221 oeuvres diverses, ne pouvait se permettre une présentation détaillée de chacun des noms ..., les lieux n'y sont munis que de coordonnées géographiques tout à fait succinctes (château, ville ou fleuve de tel pays; demeure de tel seigneur; île voisine de telle côte; etc.).

[My Table included titles from courtly romances, referring both to the romances of antiquity (the Alexander cycle, the romances of Thebes, Enéas and Troy) and to the Breton romances (Tristan and Iseut, the Arthurian romances, the Grail cycle), in both prose and verse, adventure romances and nouvelles, lais, as well as the prosimetrum Aucassin et Nicolette, etc. In total, there are 221 works and so it could not give an in-depth presentation of all names: places are only accompanied by succinct geographic markers (castle, city or river of such and such country, a given lord's domain, an island off of such and such coast, etc.)]

Creating such a reference work for other researchers of medieval French and Occitan literature took many years to complete and was, indeed, a labor of love. Even though he states that he began the task in the 1940s, it was repeatedly interrupted as Flutre was sent on mission to French West Africa and Madagascar in the 1950s. His first publications on toponymy include Pour une étude de la toponymie de l'Afrique-Occidentale française (Flutre 1957a) and Recherches sur les éléments prégaulois dans la toponymie de la Lozère(Flutre 1957b). A review of the latter by a colleague in Lyons mentions that it represented a difficult scholarly effort for someone living in Dakar, underscoring the challenges of working not only in the midst of decolonization, but also in a totally different language situation. Flutre was a Romanist, used to working in a library of historical linguistic reference materials, of the sort that he would have used to put together the Table (Gardette 1958: 214). Flutre went on to publish two articles on Africanisms found in premodern French travel narratives and an essay on toponymy in Madagascar (Flutre 1958; Flutre 1963). Although his scholarly position in this period appears somewhat precarious, the extended timeline of his research allowed Flutre to capture a large snapshot of editorial work in medieval French and Occitan, certainly way into the 1950s. The Table is well structured and systematic in its 
organization, lending itself to semi-automatic data extraction. The only other index of those mentioned above for which the same methodology would be straightforward, that is without the onerous task of disambiguating place names and person names, is Wiacek's work on the Troubadours.

\section{Flutre as Data}

The Table brings together both real and imaginary places from 221 works of imaginative fiction, mostly from the twelfth and thirteenth centuries. The geographic entries are of varying length, depending on the popularity of particular places. The work that today's spatial humanities research turns to computation to achieve (classification, disambiguation of variant spellings and matching with real locations) was done manually by Flutre in his Table. His entries list variant spellings owing to dialect and varied naming practices, suggest a geographic location when appropriate and provide an abbreviation of the work in which the spelling was found. In the case of editions lacking indexes or unedited works in manuscript, Flutre includes occasional page or folio numbers, even some relevant bibliographic references. In order that the reader might understand better how Flutre structured his Table, a few examples are given below -two real places and one imaginary one- to illustrate how he disambiguates place names, as well as how he connects those place names to texts (Flutre 1962: 191, 285, 262):

Abilam, ville et royaume d'Orient (l'ancienne Abila, aujourd'hui Nebi-Abil, au pied de l'Anti-Liban: Rom. IX, p. 29), Ber.; var. Abillan, Avilan.

Pieron(n)e, Péronne (Somme), Couci; Hunb.

Lointaines Isles (les), royaume de Galehot “devers Irlande” (=Les Hébrides?), Artur; Lanc.pr.; Merl. S.; Mort A.; Proph. M. (Lointaingnes Illes); v. Isles.

As can be seen in the examples cited, Flutre made strategic use of typographic conventions (parentheses, italics, bold, punctuation), allowing us to detect both variance and patterns in the entries. “Mort A.”, for example, is an abbreviation that refers to Frappier's 1936 edition of La Mort le roi Artu. In the second example, "(Somme)" points to a precise geographic attribution, where Flutre cites the French département in which the location can be found today. The above examples are rather straightforward, but there are other more complex entries, longer and with disambiguation when the toponym refers to many different places. To prepare the Table for use as data, optical character recognition (OCR) was applied 
to the section of the Table entitled "Noms géographiques et ethniques" and the resulting file was cleaned so that every proper name was isolated as a separate paragraph, yielding approximately 7000 geographic names and ethnonyms. The file was quite clean, but not totally free of error.

\section{Network Visualizations of Romance Places With Cytoscape and Gephi}

Since the ethnonyms were not of interest for this experiment, they were removed by looking for typical suffixes (“-ois”, “-ais”, etc.) or other words indicating groups of people ("gens”, "pays”, "peuple”, etc.) and removed. Likewise, the most ambiguous fictional place names ("chastel”, "fontaine", "isle”, etc.) were removed. Finally, using scripts in Python, the remaining data from Flutre was used to extract a list of places and the source(s) in which they are attested. ${ }^{1}$ The rationale here was to build a network of co-occurring places; the place name/text pairs were structured with a source column containing the place name using the head spelling of each entry in the Table and the target column containing the name of the work regularized to the abbreviations found in the Dictionnaire étymologique de l'ancien français (DEAF) (Möhren, n.d.), as the beginning of the data illustrates:

\section{source, target}

Abanie, Perl1N

Abanie, Floriant

Abarimacia, PercefC

Abarimacia, SGraalIIJosN

Abarimacia, Perl1N

Abarimacia, SoneG...

Network visualization is a means of visualizing a large body of information created based on the connectivity of agents. In this article we are interested in places mentioned in specific books. There are other reasons that we visualize complex systems as a network, in particular, that we can calculate the number and strength of relations that exist within a system. When we visualize this

1 I am indebted to the collaboration of my research assistant Dana Abu Ali for the extraction of the baseline data used in this article. 
dataset in Cytoscape, the network visualization environment originally designed for bioinformatics, using the circular layout, there are several details that are worthy of note. Figure 16.1 visualizes a close up of the network, with the entire circular layout of the network inset at bottom right.

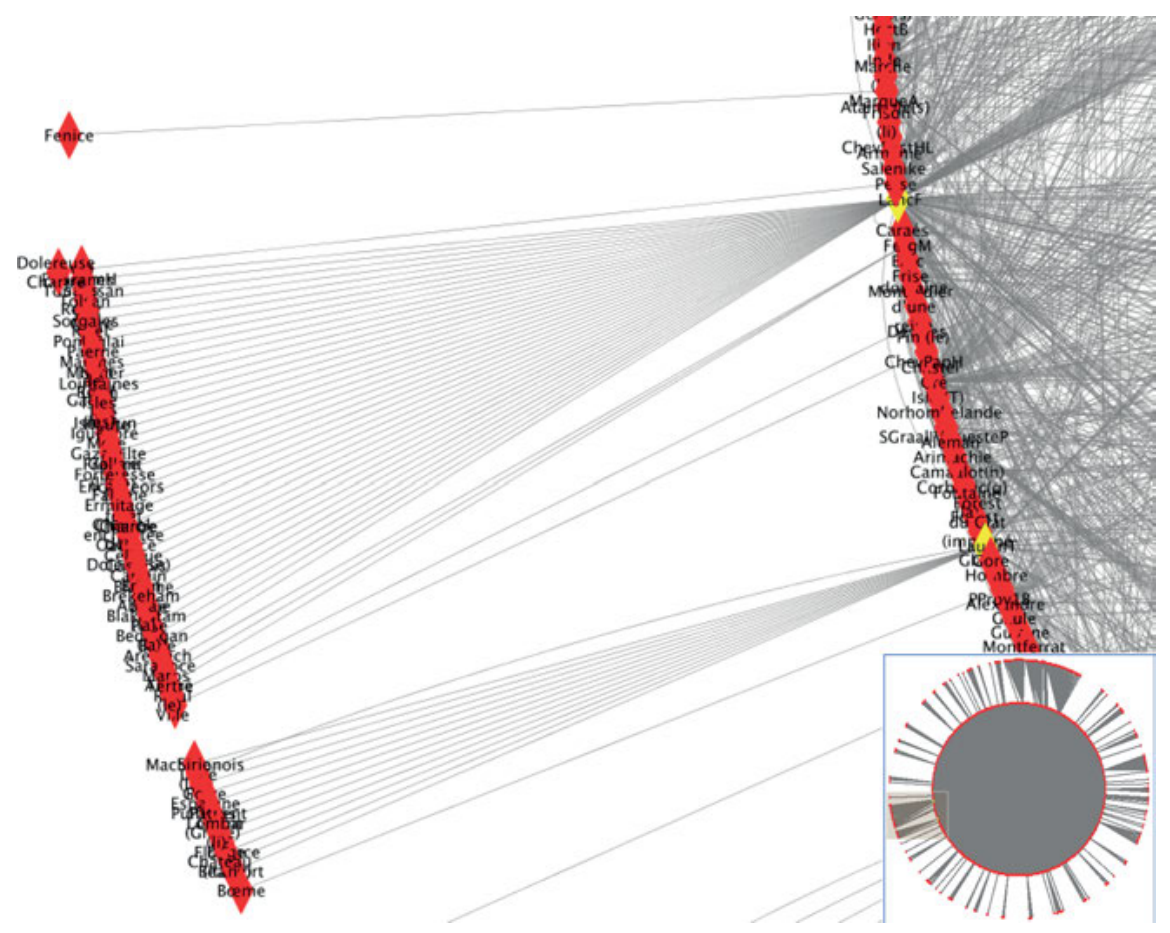

Figure 16.1: A labeled network of place names in medieval French literature extracted from a canonical index (Flutre 1962), visualized using a circular layout in Cytoscape.

The nodes, colored in red, are the abbreviated titles of works and places mentioned in the works. One notices immediately that there are numerous single edges that emerge as an outer ring (at left) from the main circular structure of the graph visualization, and within the circle, we see a dense network of edges connecting the red nodes within the circle. The interior, grey edges indicate repeated places, whereas those that fan out of the circle are singular, unconnected place names mentioned only once. These are the toponyms that function like hapaxes in the Table. In fact, one of the more significant preliminary findings of a network visualization of place in medieval French courtly literature is that some of the texts in Flutre's Table are actually full of names occurring 
only once. Two nodes have been selected and visualized in yellow in Figure 16.1: Chrétien de Troyes' Le chevalier de la charrette (LancF) and the Roman de Laurin (Laurin). Other important texts that exhibit this same phenomenon include the decasyllabic Arsenal version of the Roman d'Alexandre, the Roman de Troie, Perceforest and Melusine.

The pattern of single edges discovered above can also be clearly visualized in the network graph software, Gephi. Using the same data as above, a community detection algorithm (Blondel/Guillaume/Lambiotte/Lefebvre 2008: 1000) and the Force Atlas 2 layout (Jacomy/Venturini/Heymann/Bastian 2014: e98679) were applied, and nine communities came into focus, each indicated below by a separate color:

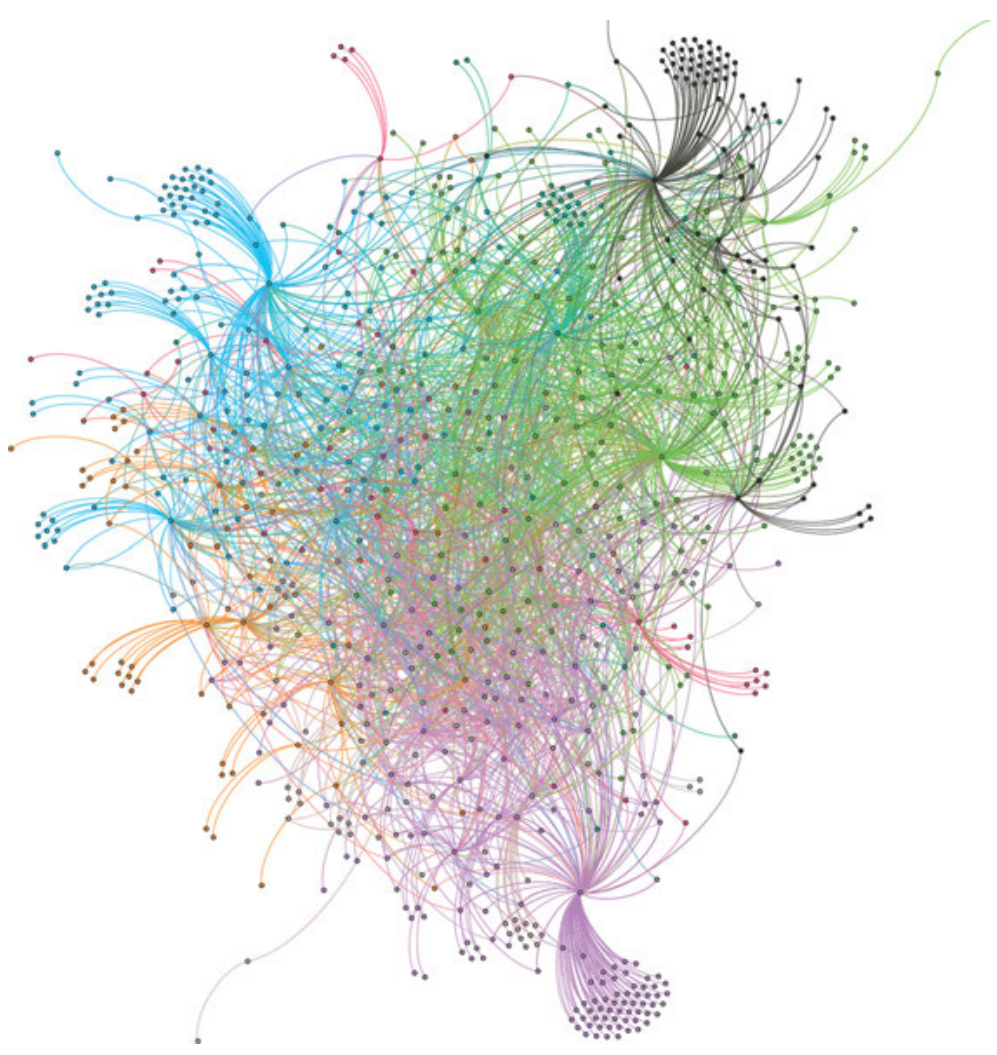

Figure 16.2: An unlabeled force-directed graph of place names in medieval courtly French literature with curved edges visualized in Gephi using the ForceAtlas2 layout algorithm and community detection. The data has been extracted from a canonical index (Flutre 1962). 
The singular edges we see sitting outside of the circular view in the Cytoscape ring visualization appear in Gephi as distinctive "hubs" at the edges of the network, fanning out like brushes, distinct from the denser central core of connected places. Whereas the layout in Cytoscape in Figure 16.1 locates the more connected edges within a large circle, force-directed layouts as in Figure 16.2 push the most connected nodes to the edge of the graph (Bostock 2017: n.p.). The data in the two figures are the same, but the two different visual layouts allow us to see different aspects of the data. The aforementioned finding does not mean necessarily that the places found in these texts are necessarily fictional, however, a quick spot check of these one time occurring name clusters revealed many places that do not correspond easily to real geographies. While it is tempting to conclude from such visualizations that medieval French romances abound in singular places or places of the imagination, it is also important to mention, however, that the texts containing the many single mention of places are the very same ones that contain many more place names than on average, including many real geographic places.

The community detection process marked by colors in Figure 16.2 deserves further investigation. Community detection is a means in network analysis of identifying clusters of nodes with a higher probability of being connected to each other than to other nodes. If we look at the communities that the Gephi algorithm generated, it would suggest that the common places shared between clusters of the romance genre might serve as a rough index for their classification into sub-genres. In other words, the detected communities match more or less the different sub-categories of romances described by Flutre as making up the corpus that he used to compose his index. Let us return for a moment to the introduction to the Table, in which Flutre provides a general breakdown of the composition of the 221 works he analyzed: romances of antiquity, Greco-Byzantine romances, Breton romances, adventure romances, verse courtly texts, didactic love poems, etc. (Flutre 1962: vii-viii). Literary historians know that generic divisions are, of course, approximate in nature, but in Figure 16.2, we observe a basic correspondence between communities and the Flutre's groupings of texts. The community detection algorithm groups the Alexander texts (in pink) together as sharing the same places. As well, we see Breton romances (in green) and romances of antiquity (in orange). Were it only for these clusters it could be easy to say that the sheer numbers of places in these genres make them stand out in the graph, however, other groupings are visible, Arthurian fiction (in black), and then a less obvious grouping including the Perceforest (in dark red). In other words, romances belonging to the same sub-genres seem to contain many of the same places, suggesting a topical rather than purely real world referential status. This is a finding that needs to be investigated further. 
The data from Flutre were modeled as an undirected network, meaning that there is no particular hierarchy between the source (text) and target (place) nodes. Using the notion of weighted degree, that is, a measure of the number of edges for every node, we can also look for the texts and places with the highest numbers of connections in the network. Figure 16.3 visualizes the same network as in the above figure, but the least connected places have been filtered out. What is left is a network of the most significant, co-occurring places.

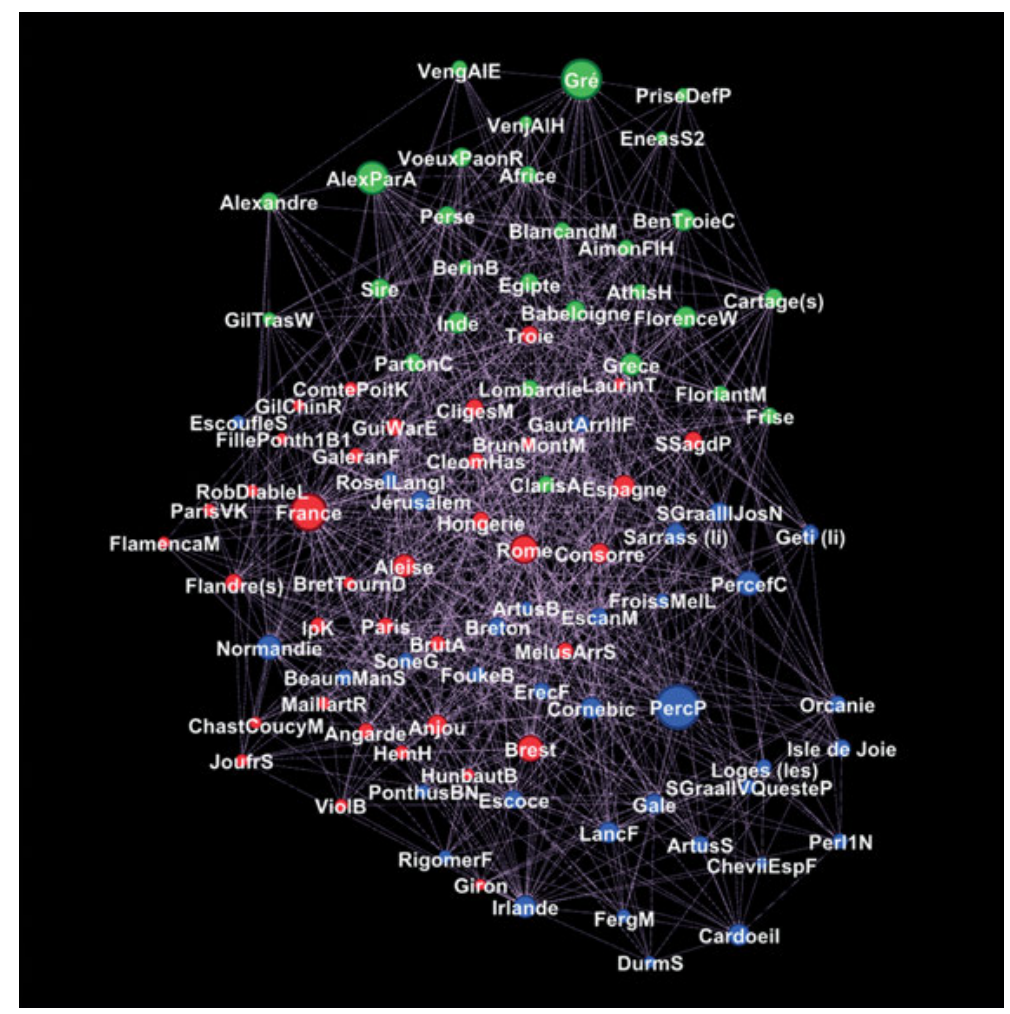

Figure 16.3: A labeled network of place names in medieval French literature extracted from a canonical index (Flutre 1962), visualized in Gephi, illustrating weighted degree of the nodes, filtered to illustrate the places and texts of highest frequency. Colors (red, green and blue) illustrate three major communities.

The size of the circles (representing nodes) in the graph is directly proportional to the frequency of occurrences of the place. It is worth reiterating that in our model, no difference is asserted between real and imaginary places (or places 
of uncertain or very general regional location). Real places such as "France", "Egipte”, "Brest” and "Rome” sit alongside "Gré”, “Troie” and "Consorre” as very frequent places of medieval French romance. In the face of such evidence, we are drawn to the conclusion that in romance texts, places are a topical marker. In Figure 16.3 color is also used to indicate community, and three distinct communities are among the most central of this filtered place name network: green for the Alexander romances and the romances of antiquity, blue for Arthurian material and red for northern French romances. Also quite interesting to mention are other highly connected places sitting at the center of the network that are located geographically outside of France: those of the north "Cardoeil", "Escoce”, "Irlande”, "Gale”; the Italian and Mediterranean "Rome”, "Egipte”, “Aumarie”, "Africe” and the central European, "Saisogne”, "Hongerie."

If the same data had been visualized on a map showing all the places mentioned in medieval French texts, we would have the impression that these geographies are far from the center, however, the frequency-based network visualization approach based shows how they are quite significant to the network, that is, in a position of topical centrality. Whereas classic studies on geography in medieval French literature have focused on urban geographic references in the capital city of France, Paris (Olschki 1913; Planche 1979: 60-69) and limited work has been done to discuss regional geographies and their importance within medieval French romance (Lozinskij 1929: 71-88), my findings suggest that much more can be done to discuss the comparative topical importance of these Mediterranean, northern and central European places. Is it possible to find, for example, in the vernacular courtly literature both geographies of court power and "une poétique de la géographie, fondée sur l'utilisation de lieux communs inlassablement répétés et sur la sonorité des noms de lieux" [a poetics of geography, founded on endlessly repeated commonplaces and on the sounds of place names]? (Bouloux 1993: 137).

\section{Conclusion}

The purpose of this article was not to study the origin and meaning of proper names from the perspective of onomastics or toponymy, nor was it to focus on the medieval concept of place or even to try to put places on normative modern maps, but rather to assess the frequency of place names across a corpus of "courtly literature" (represented by Flutre's Table) and visualize those frequencies using the abstract model of a network. The data from Flutre do not represent raw numbers of mentions of place names in a corpus, but rather they derive from a structured index of place names. This means that the "one text, one mention" principle 
applies. In future work, it would be desirable to expand the notion of the network to include other measures of centrality and distance, in particularly with a textbase on the basis of which such measures could be calculated (Beshero-Bondar 2018: n. p.). It would be possible, even desirable, to replicate the methodology used here with all of medieval French literature, using the data contained in the indexes compiled by Langlois, Wiacek, West and Moisan to see how the results vary across genres, although that task would require a significant investment of time and energy.

Expanding the model to use other printed material is complicated by several factors, however, the most straightforward of them being that proper names do not only include places and people, but also personal names, for which there are not yet data that allow for easy disambiguation. One could imagine extending such an approach to place across a network of historical or religious texts as well, as well as the same principle being applied to other medieval languages, Latin and/or the vernaculars. Here again, we are constrained by the limits of historical lexical resources particularly with respect to orthographic variation found in named entities. It is worth considering if Flutre's printed resources might be combined with the others mentioned here into the "spine" of such a historical place name database, in other words, a gazetteer. In this respect, perhaps the next likely candidate for repeating the experiment is Moisan's Répertoire. The typographic nature of the latter, reproduced based on dot-matrix computer print-outs from the 1980 s makes it a tricky candidate for clean OCR, but the author has constructed his work such that place names have been already disambiguated. In any case, the network model is particularly useful for romance, and Flutre's data was able to be harvested with reasonable effort. The network visualization approach has allowed us to discover the importance of regional toponyms (e.g. "Lombardie" or "Egipte") in the corpus, a mapping of which would not necessarily be visually significant.

\section{Works Cited}

Barbaresi, Adrien (2018): “Toponyms as Entry Points into a Digital Edition: Mapping Die Fackel”. In: Open Information Science, 2.1, pp. 23-33.

Beshero-Bondar, Elisa (2018): “Juxtapositions of Place in Thalaba the Destroyer". Online at: https://ebeshero.github.io/thalaba/graphs.html. Consulted 25 June 2018.

Biber, Douglas (2011): “Corpus Linguistics and the Study of Literature: Back to the Future”. In: Scientific Study of Literature, 1.1, pp. 15-23. 
Blondel, Vincent D./Guillaume, Jean-Loup/Lambiotte, Renaud/Lefebvre, Etienne (2008): “Fast unfolding of communities in large networks". In: Journal of Statistical Mechanics: Theory and Experiment, 10, p. 10008.

Borin, Lars/Dannélls, Dana/Olsson, Leif-Jöran (2014): “Geographic Visualization of Place Names in Swedish Literary Texts". In: Literary and Linguistic Computing, 29.3, pp. 400-404.

Bouloux, Nathalie (1993): "Les usages de la géographie à la cour des Plantagenêts dans la seconde moitié du XIlè siècle”. In: Médiévales, 24, pp. 131-148.

Bostock, Mike (2017). “Force-Directed Graph”. Online at: https://bl.ocks.org/ mbostock/4062045. Consulted 29 March 2018.

Chambers, Frank M. (1971): Proper Names in the Lyrics of the Troubadours. Chapel Hill: Department of Romance Studies.

Dauphant, Léonard (2018): Géographies: Ce qu'ils savaient de la France (1100-1600). Ceyzérieu: Champ Vallon.

Donaldson, Christopher Elliott/Murrieta-Flores, Patricia/Gregory, Ian Norman (2016): “Distant Readings of the Geographies in Text Corpora: Mapping Norman Nicholson's Poems and Letters". In: Wieneke, Lars/Jones, Catherine/Düring, Martin/Armaselu, Florentina/ Leboutte, René (eds.): Proceedings of the Third Conference on Digital Humanities in Luxembourg with a Special Focus on Reading Historical Sources in the Digital Age. Aachen: CEUR Workshop Proceedings, n.p.

Flutre, Louis-Fernand (1957a): Pour une étude de la toponymie de l'Afrique-Occidentale Française. Dakar: Faculté de Lettres de l'Université de Dakar.

Flutre, Louis-Fernand (1957b): Recherches sur les éléments prégaulois dans la toponymie de la Lozère. Paris: Les Belles Lettres.

Flutre, Louis-Fernand (1958): “De quelques termes usités aux XVIle et XVIIle siècles sur les côtes de l'Afrique Occidentale et qui ont passé dans les récits des voyageurs français du temps”. In: Hans-Erich Keller (ed.): Etymologica. Festschrift Walther von Wartburg zum siebzigsten Geburtstag. Tübingen: Niemeyer, pp. 209-238.

Flutre, Louis-Fernand (1962): Table des noms propres avec toutes leurs variantes figurant dans les romans du Moyen Âge écrits en français ou en provençal et actuellement publiés ou analysés. Poitiers: Centre d'études supérieures de civilisation médiévale.

Flutre, Louis-Fernand (1963): "De l'apport de Madagascar au vocabulaire du français d'outre-mer aux XVIIe et XVIIIe siècles”. In: Annale malgache, 1, pp. 3-21.

Flutre, Louis-Fernand (1971): "G.D. West. - An Index of Proper Names in French Arthurian Verse Romances, 1150-1300”. In: Cahiers de civilisation médiévale, 56, pp. 401-403.

Gardette, Pierre (1958): “Louis-Ferdinand Flutre, Pour une étude de la toponymie de l'A.O.F.”. In: Revue de géographie de Lyon, 33.2, pp. 214-215.

Harrison, Dick (1996): Medieval Space: The Extent of Microspatial Knowledge in Western Europe in the Middle Ages. Lund: Lund University Press.

Haslhofer, Bernhard/Isaac, Antoine/Simon, Rainer (2018): “Knowledge Graphs in the Libraries and Digital Humanities". In: Domain Arxiv [Online at: https://arxiv.org/pdf/1803.03198. pdf. Consulted: 20 March 2018].

Henige, David (2007): “'This is the Place:' Putting the Past on the Map”. In: Journal of Historical Geography, 33, pp. 237-253.

Jacomy, Mathieu/Venturini, Tommaso/Heymann, Sebastien/Bastian, Mathieu (2014):

"ForceAtlas2, a Continuous Graph Layout Algorithm for Handy Network Visualization

Designed for the Gephi Software”. In: PLoS ONE, 9(6),p. e98679 [Online at http://journals. plos.org/plosone/article?id=10.1371/journal.pone.0098679, consulted 30 June 2018] 
Jeay, Madeleine (2006): Le commerce des mots: l'usage des listes dans la littérature médiévale (XII $-\mathrm{XV}$ siècles). Geneva: Droz.

Langlois, Ernest (1904): Table des noms propres de toute nature compris dans les chansons de geste imprimées. Paris: É. Bouillon.

Lozinskij, Grégoire (1929): “La Russie dans la littérature française du Moyen Âge: le pays”. In: Revue des études slaves, 9.1-2, pp. 71-88.

Möhren, Frankwalt (n.d.): “DEAFBiblEl: Complément bibliographique”. In: Dictionnaire étymologique de l'ancien français (DEAF). [Online at: http://www.deaf-page.de/fr/bibl_ neu.php. Consulted 29 March 2018].

Moisan, André (1986): Répertoire des noms propres de personnes et de lieux cités dans les chansons de geste françaises et les œuvres étrangères dérivées. Geneva: Droz.

Moretti, Franco (2017): “Patterns and Interpretation”. In: Literary Lab Pamphlet, 15, [Online at: https://litlab.stanford.edu/LiteraryLabPamphlet15.pdf. Consulted 20 March 2018].

Olschki, Leonardo (1913): Paris nach den altfranzösischen nationale Epen: Topographie, Stadtgeschichte und lokale Sagen. Heidelberg: Carl Winters.

Padilla, Thomas (2017): “On a Collections as Data Imperative”. UC Santa Barbara. [Online at: https://escholarship.org/uc/item/9881c8sv. Consulted 15 January 2018].

Peregrino, Fernando S./Tomás, David/Llopis, Fernando (2013): “Una aproximación basada en corpus para la detección del foco geográfico en el texto". In: Procesamiento del Lenguaje Natural, 50, pp. 69-76.

Planche, Alice (1979): “Présence et absence de Paris dans la littérature jusqu’au milieu du XIIle siècle”. In: L'image de la ville dans la littérature et l'histoire médiévales. Nice: Centre d’Études médiévales, pp. 60-69.

West, G.D. (1969): An Index of Proper Names in French Arthurian Verse Romances: 1150-1300. Toronto: University of Toronto Press.

West, G.D. (1978): An Index of Proper Names in French Arthurian Prose Romances. Toronto/ Buffalo/London: University of Toronto Press.

Wiacek, Wilhelmina M. (1968): Lexique des noms géographiques et ethniques dans les poésies des troubadours des XIIe et XIIle siècles. Paris: Nizet.

Wrisley, David Joseph (2017): “Locating Medieval French, or Why We Collect and Visualize the Geographic Information of Texts”. In: Speculum: A Journal of Medieval Studies, 92.S1, pp. S145-S169. 
